\title{
Renal vascularisation anomalies in the Polish population. Coexistence of arterial and venous anomalies in the vascular pedicle of the kidney
}

\author{
H. Sośnik, K. Sośnik \\ Department of Pathomorphology, Regional Specialist Hospital, Wrocław, Poland \\ [Received: 22 April 2018; Accepted: 19 July 2018]
}

Background: The aim of the study was to determine the coexistence of arterial and venous anomalies in the vascular pedicle of the kidney in the Polish population. Materials and methods: The study group comprised 550 corpses, including 281 male (mean age $52 \pm 22$ years), and 269 female corpses (mean age $56.4 \pm$ \pm 23 years) $(p=0.02)$. The vascular bundle was removed together with the kidney, "en bloc"; the vessels were subject to radiological contrasting and preparation. The obtained results were subject to statistical analysis (the exact Fisher test, $\chi^{2}$ test of independence for cross-tabulation $2 \times 2$ tables, and the odds ratio with the confidence interval at a level of 0.95, calculated on the basis of the contingency dependence). Statistica 12 and Microsoft Excel were used for calculations. Results: Variations in the structure of the renal venous system were observed in 33.8\%; insignificantly more often in male (35.9\%), as compared to female patients (31.6\%). Deviations in the structure of the renal arteries were observed significantly more often in patients with renal venous system developmental disorders $(p=0.0071)$. In patients with a normal renal venous system, arterial kidney structure deviations were observed in $34.9 \%$ of cases, significantly more often in male (40\%), as compared to female (29.7\%) patients $(p=0.043)$. On the other hand, in venous system pathologies, the above-mentioned deviations were observed in $46.8 \%$ of cases $(p=0.002)$. Amongst developmental anomalies of the venous system, right-sided venous excess was observed in $20.4 \%$ of cases, including $48 \%$ of renal artery developmental pathologies, significantly more often in male (61.3\%), as compared to female (32\%) patients $(p=0.002)$.

Conclusions: Renal artery anomalies of the kidney vascular pedicle are significantly correlated with the coexistence of venous system variations. This is especially true for male patients, which favours female kidneys for transplantation. (Folia Morphol 2019; 78, 2: 290-296)

Key words: renal vascular pedicle, arterial and venous anomalies, correlations

\section{INTRODUCTION}

Variations in the structure of the renal vascular pedicle occur relatively frequently [11, 29], which should be considered in surgical treatment of aortic aneurysms $[2,26]$, during retroperitoneal procedures $[3,12]$, in the treatment of renovascular hypertension [5], as well as during kidney transplantation $[4,6,7,14,20]$.

Address for correspondence: H. Sośnik, MD, PhD, Department of Pathomorphology, Regional Specialist Hospital, ul. St. Jaracza 82B/4, 50-305 Wroctaw, Poland, tel: +48 7179141 29, e-mail: henryksosnik@gmail.com 
In studies performed on a large sectional material, excess arteries ranged between $19.1 \%$ [23] and $32.3 \%$ [21]. In our own material the above-mentioned amounted to $38.3 \%$ [27]. The percentage of variations in the structure of the venous system was also high. Pick and Anson [21] observed $14.4 \%$ of such cases, while in our previous investigations the abovementioned amounted to $33.8 \%$ [28].

Developmental disorders of the renal arteries are often accompanied by deviations of the venous structure $[16,30]$. It is suggested that both anomalies go hand-in-hand [3, 21].

We decided to investigate the problem in the Polish population.

\section{MATERIALS AND METHODS}

The study group comprised 550 deceased patients, including 281 men, aged between 0.2 and 91 years (mean age $52 \pm 22.6$ years), and 269 women, aged between 0.1 and 92 years (mean age $56.4 \pm$ \pm 23 years) ( $p=0.02)$ (approval of the Bioethical Committee No. 2/ BOPD/2017 DIL).

The renovascular samples were removed from the deceased bodies, "en bloc". In 377 (68.5\%) cases postmortal aortonephrography was performed, while in 145 (26.4\%) - cavonephrography. After 2-week fixation in a $10 \%$ formalin solution, each prepared sample was subjected to description (Figs. 1, 2). The methodology was mentioned in our previous studies $[27,28]$. The obtained statistical data was subjected to analysis by means of the exact Fisher test, and $\chi^{2}$ test of independence for cross-tabulation $2 \times 2$ tables. The odds ratio (OR) with a confidence interval $(\mathrm{Cl})$ at a level of 0.95 was calculated in the case of significant contingency (dependence). The $\chi^{2}$ test was used to verify the uniform distribution of subgroups of bodies with different renal vessel anomalies. Statistica 12 software and Microsoft Excel were used for calculation.

\section{RESULTS}

Results are presented in two stages:

- the occurrence of arterial variations in relation to the number of renal veins (1100 kidneys);

- occurrence of variations in the structure of arterial system in relation to particular types of developmental disorders of the venous system (7 types in our material; 550 cases).

The percentage of excess arteries significantly increased with the number of renal veins (Fig. 3, Table 1). Considering the side of the body, the number of arterial

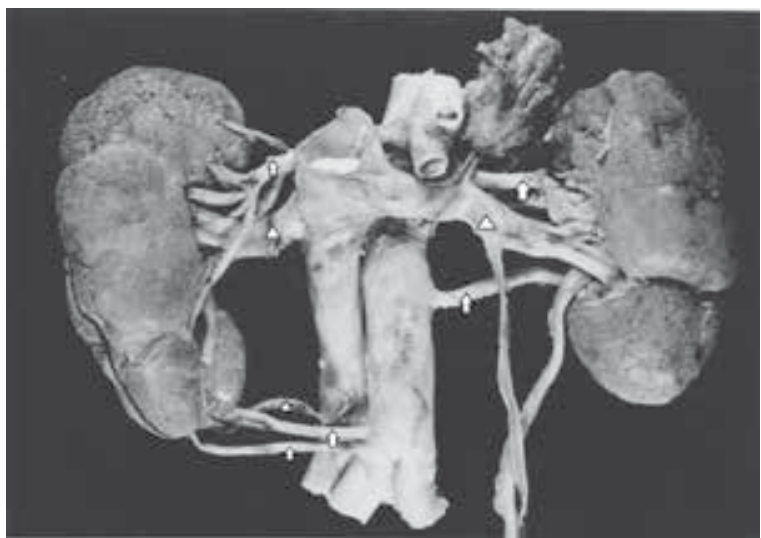

Figure 1. Vasculorenal sample in the antero-posterior position. Two left renal arteries (arrows) running parallel with left renal vein (arrowhead) to the left kidney hilum. Three renal arteries (arrows) and two renal veins (arrowheads) on the right side. Two accessory renal arteries running precaval and parallel with an accessory renal vein to the inferior pole of right kidney. Right renal artery and vein in normal position.

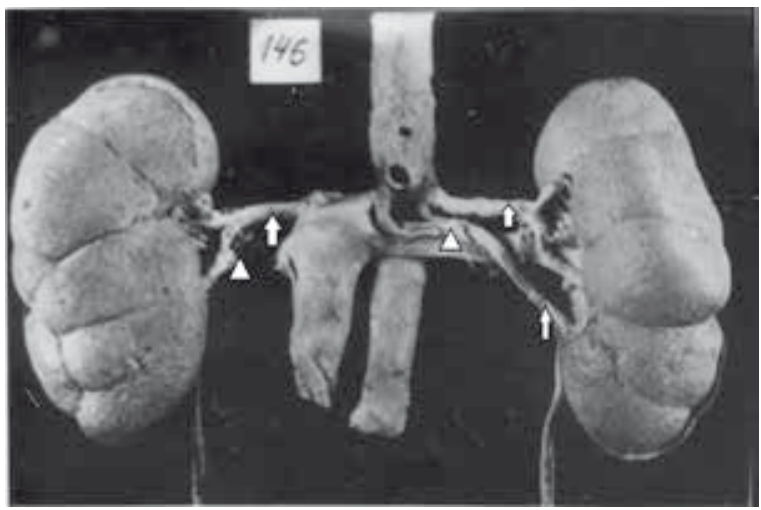

Figure 2. Vasculorenal sample in the antero-posterior position. On the left side two renal arteries (arrows). One of them wrapping around the left renal vein (arrowhead), running to the left kidney hilum. Normal arterio-venous position on the right side.

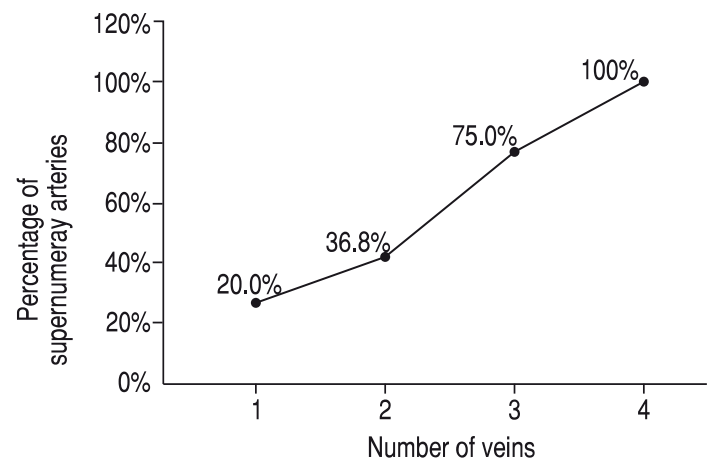

Figure 3. Percentage of supernumerary arteries depending on number of veins. 
Table 1. Arterial-venous coincidence in the vascular bundle of kidney (1100 kidneys)

\begin{tabular}{|c|c|c|c|c|c|c|c|}
\hline \multirow{2}{*}{$\begin{array}{l}\text { Number of } \\
\text { veins }\end{array}$} & \multicolumn{4}{|c|}{ Number of arteries } & \multirow[t]{2}{*}{ Total } & \multicolumn{2}{|c|}{ Supernumerary arteries } \\
\hline & 1 & 2 & 3 & 4 & & Sum & Percentage \\
\hline 1 & 738 & 172 & 9 & 4 & 923 & 185 & $20.0 \%$ \\
\hline 2 & 103 & 48 & 10 & 2 & 163 & 60 & $36.8 \%$ \\
\hline 3 & 3 & 4 & 4 & 1 & 12 & 9 & $75.0 \%$ \\
\hline 4 & 0 & 0 & 1 & 1 & 2 & 2 & $100.0 \%$ \\
\hline Total & 844 & 224 & 24 & 8 & 1100 & 256 & $23.3 \%$ \\
\hline
\end{tabular}

P-values: 1-2: 0.0000, 1-3: 0.0000, 1-4: 0.005, 2-3: 0.009, 2-4: 0.067, 3-4: 0.42

Table 2. Arterial-venous coincidence in the vascular bundle of kidney depending on the side of body $(n=550)$

\begin{tabular}{|c|c|c|c|c|c|c|c|c|c|c|}
\hline \multicolumn{5}{|c|}{ Right kidney } & \multirow[t]{2}{*}{$\mathbf{P}$} & \multicolumn{5}{|c|}{ Left kidney } \\
\hline $\begin{array}{l}\text { Number } \\
\text { of veins }\end{array}$ & $\begin{array}{l}\text { Number of } \\
\text { arteries }\end{array}$ & $\begin{array}{l}\text { Number of } \\
\text { kidneys }\end{array}$ & $\begin{array}{l}\text { Per } \\
\text { cent }\end{array}$ & $\begin{array}{l}\text { Per cent of super- } \\
\text { numerary arteries }\end{array}$ & & $\begin{array}{c}\text { Number of } \\
\text { veins }\end{array}$ & $\begin{array}{l}\text { Number of } \\
\text { arteries }\end{array}$ & $\begin{array}{l}\text { Number of } \\
\text { kidney }\end{array}$ & $\begin{array}{l}\text { Per } \\
\text { cent }\end{array}$ & $\begin{array}{l}\text { Per cent of super- } \\
\text { numerary arteries }\end{array}$ \\
\hline \multirow[t]{4}{*}{1} & 1 & 341 & $82.8 \%$ & \multirow{4}{*}{$17.2 \%$} & \multirow{4}{*}{0.056} & 1 & 1 & 397 & $77.7 \%$ & \multirow{4}{*}{$22.3 \%$} \\
\hline & 2 & 66 & $16.0 \%$ & & & & 2 & 106 & $20.7 \%$ & \\
\hline & 3 & 4 & $1.0 \%$ & & & & 3 & 5 & $1.0 \%$ & \\
\hline & 4 & 1 & $0.2 \%$ & & & & 4 & 3 & $0.6 \%$ & \\
\hline \multirow[t]{4}{*}{2} & 1 & 85 & $67.5 \%$ & \multirow{4}{*}{$32.5 \%$} & \multirow{4}{*}{0.055} & 2 & 1 & 18 & $50.0 \%$ & \multirow{4}{*}{$50.0 \%$} \\
\hline & 2 & 34 & $27.0 \%$ & & & & 2 & 14 & $38.9 \%$ & \\
\hline & 3 & 6 & $4.8 \%$ & & & & 3 & 4 & $11.1 \%$ & \\
\hline & 4 & 1 & $0.8 \%$ & & & & 4 & 0 & $0.0 \%$ & \\
\hline \multirow[t]{4}{*}{3} & 1 & 3 & $30.0 \%$ & \multirow{4}{*}{$70.0 \%$} & \multirow{4}{*}{0.71} & 3 & 1 & 1 & $33.3 \%$ & \multirow{4}{*}{$66.7 \%$} \\
\hline & 2 & 3 & $30.0 \%$ & & & & 2 & 1 & $33.3 \%$ & \\
\hline & 3 & 3 & $30.0 \%$ & & & & 3 & 1 & $33.3 \%$ & \\
\hline & 4 & 1 & $10.0 \%$ & & & & 4 & 0 & $0.0 \%$ & \\
\hline \multirow[t]{4}{*}{4} & 1 & 0 & $0.0 \%$ & \multirow{4}{*}{$100.0 \%$} & \multirow{4}{*}{-} & 4 & 1 & 0 & - & \multirow{4}{*}{-} \\
\hline & 2 & 0 & $0.0 \%$ & & & & 2 & 0 & - & \\
\hline & 3 & 1 & $50.0 \%$ & & & & 3 & 0 & - & \\
\hline & 4 & 1 & $50.0 \%$ & & & & 4 & 0 & - & \\
\hline
\end{tabular}

variations was significantly greater on the left side, especially in kidneys with one or two renal veins (Table 2).

Gender also had significantly influence on the occurrence of arterial system deviations, in relation to the number of renal veins, although only in kidneys with a single renal vein. The above-mentioned ratio was lower in female (14.8\%), as compared to male patients $(25.3 \%)(p=0.0001)$ (Table 3 ).

In male patients the percentage of excess arteries was significantly greater on the left side in the case of kidneys with one or two renal veins (Table 4). Such differences were not seen in women (Table 5).

Amongst the 7 types of venous renal system structure variations, considering 550 bodies, 214 were diagnosed with arterial kidneys structure variations (38.9\%), significantly more often in men (46.6\%), as compared to women (30.9\%; $p=0.0002)$.
In patients with "normal" venous system structure (both-sided, single vein), 34.9\% of arterial kidney structure variations were observed, significantly more often in male (40\%), as compared to female patients (29.89\%; $p=0.043$ ).

Rows 2-7 of Table 6, present the particular types of venous system structure abnormalities. Amongst the above-mentioned, isolated right-sided venous excess $(112 / 550 ; 20.4 \%)$ was observed significantly more often ( $p=0.005$ ), including $48.2 \%$ of arterial system variation, significantly more often in men (38/62; 61.3\%), as compared to women (16/50; 32\%; $p=0.002)$. Amongst the remaining 74 venous system, structure variations (13.5\%), the retroaortic course of the left kidney vein accounted for $31.1 \%$, while the periaortic venous ring $-28.4 \%$. 
Table 3. Arterial-venous coincidence in the vascular bundle of kidney depending on the sex of body $(n=550)$

\begin{tabular}{|c|c|c|c|c|c|c|c|c|c|c|}
\hline \multicolumn{5}{|c|}{ Male (n= 281) } & \multirow[t]{2}{*}{$\mathbf{P}$} & \multicolumn{5}{|c|}{ Female $(n=269)$} \\
\hline $\begin{array}{l}\text { Number } \\
\text { of veins }\end{array}$ & $\begin{array}{l}\text { Number of } \\
\text { arteries }\end{array}$ & $\begin{array}{l}\text { Number of } \\
\text { kidneys }\end{array}$ & $\begin{array}{l}\text { Per } \\
\text { cent }\end{array}$ & $\begin{array}{l}\text { Per cent of super- } \\
\text { numerary arteries }\end{array}$ & & $\begin{array}{l}\text { Number } \\
\text { of veins }\end{array}$ & $\begin{array}{c}\text { Number of } \\
\text { arteries }\end{array}$ & $\begin{array}{c}\text { Number of } \\
\text { kidneys }\end{array}$ & $\begin{array}{l}\text { Per } \\
\text { cent }\end{array}$ & $\begin{array}{l}\text { Per cent of super- } \\
\text { numerary arteries }\end{array}$ \\
\hline \multirow[t]{4}{*}{1} & 1 & 345 & $74.7 \%$ & \multirow{4}{*}{$25.3 \%$} & \multirow{4}{*}{0.0001} & 1 & 1 & 393 & $85.2 \%$ & \multirow{4}{*}{$14.8 \%$} \\
\hline & 2 & 107 & $23.2 \%$ & & & & 2 & 65 & $14.1 \%$ & \\
\hline & 3 & 6 & $1.3 \%$ & & & & 3 & 3 & $0.7 \%$ & \\
\hline & 4 & 4 & $0.9 \%$ & & & & 4 & 0 & $0.0 \%$ & \\
\hline \multirow[t]{4}{*}{2} & 1 & 54 & $59.3 \%$ & \multirow{4}{*}{$40.7 \%$} & \multirow{4}{*}{0.163} & 2 & 1 & 49 & $68.1 \%$ & \multirow{4}{*}{$31.9 \%$} \\
\hline & 2 & 30 & $33.0 \%$ & & & & 2 & 18 & $25.0 \%$ & \\
\hline & 3 & 7 & $7.7 \%$ & & & & 3 & 3 & $4.2 \%$ & \\
\hline & 4 & 0 & $0.0 \%$ & & & & 4 & 2 & $2.8 \%$ & \\
\hline \multirow[t]{4}{*}{3} & 1 & 2 & $28.6 \%$ & \multirow{4}{*}{$71.4 \%$} & \multirow{4}{*}{0.64} & 3 & 1 & 1 & $20.0 \%$ & \multirow{4}{*}{$80.0 \%$} \\
\hline & 2 & 2 & $28.6 \%$ & & & & 2 & 2 & $40.0 \%$ & \\
\hline & 3 & 2 & $28.6 \%$ & & & & 3 & 2 & $40.0 \%$ & \\
\hline & 4 & 1 & $14.3 \%$ & & & & 4 & 0 & $0.0 \%$ & \\
\hline \multirow[t]{4}{*}{4} & 1 & 0 & $0.0 \%$ & \multirow{4}{*}{$100.0 \%$} & \multirow{4}{*}{-} & 4 & 1 & 0 & - & \multirow{4}{*}{-} \\
\hline & 2 & 0 & $0.0 \%$ & & & & 2 & 0 & - & \\
\hline & 3 & 1 & $50.0 \%$ & & & & 3 & 0 & - & \\
\hline & 4 & 1 & $50.0 \%$ & & & & 4 & 0 & - & \\
\hline
\end{tabular}

Table 4. Arterial-venous coincidence in the vascular bundle of kidney depending on the side of male body $(\mathrm{n}=281)$

\begin{tabular}{|c|c|c|c|c|c|c|c|c|c|c|}
\hline \multicolumn{5}{|c|}{ Right kidney } & \multirow[t]{2}{*}{$\mathbf{P}$} & \multicolumn{5}{|c|}{ Left kidney } \\
\hline $\begin{array}{l}\text { Number } \\
\text { of veins }\end{array}$ & $\begin{array}{c}\text { Number } \\
\text { of arteries }\end{array}$ & $\begin{array}{c}\text { Number } \\
\text { of kidneys }\end{array}$ & $\begin{array}{l}\text { Per } \\
\text { cent }\end{array}$ & $\begin{array}{l}\text { Per cent of super- } \\
\text { numerary arteries }\end{array}$ & & $\begin{array}{l}\text { Number } \\
\text { of veins }\end{array}$ & $\begin{array}{l}\text { Number of } \\
\text { arteries }\end{array}$ & $\begin{array}{c}\text { Number } \\
\text { of kidneys }\end{array}$ & $\begin{array}{l}\text { Per } \\
\text { cent }\end{array}$ & $\begin{array}{l}\text { Per cent of super- } \\
\text { numerary arteries }\end{array}$ \\
\hline \multirow[t]{4}{*}{1} & 1 & 162 & $79.0 \%$ & \multirow{4}{*}{$21.0 \%$} & \multirow{4}{*}{0.035} & 1 & 1 & 183 & $71.2 \%$ & \multirow{4}{*}{$28.8 \%$} \\
\hline & 2 & 40 & $19.5 \%$ & & & & 2 & 67 & $26.1 \%$ & \\
\hline & 3 & 2 & $1.0 \%$ & & & & 3 & 4 & $1.6 \%$ & \\
\hline & 4 & 1 & $0.5 \%$ & & & & 4 & 3 & $1.2 \%$ & \\
\hline \multirow[t]{4}{*}{2} & 1 & 45 & $65.2 \%$ & \multirow{4}{*}{$34.8 \%$} & \multirow{4}{*}{0.039} & 2 & 1 & 9 & $40.9 \%$ & \multirow{4}{*}{$59.1 \%$} \\
\hline & 2 & 20 & $29.0 \%$ & & & & 2 & 10 & $45.5 \%$ & \\
\hline & 3 & 4 & $5.8 \%$ & & & & 3 & 3 & $13.6 \%$ & \\
\hline & 4 & 0 & $0.0 \%$ & & & & 4 & 0 & $0.0 \%$ & \\
\hline \multirow[t]{4}{*}{3} & 1 & 2 & $40.0 \%$ & \multirow{4}{*}{$60.0 \%$} & \multirow{4}{*}{0.67} & 3 & 1 & 0 & $0.0 \%$ & \multirow{4}{*}{$100.0 \%$} \\
\hline & 2 & 1 & $20.0 \%$ & & & & 2 & 1 & $50.0 \%$ & \\
\hline & 3 & 1 & $20.0 \%$ & & & & 3 & 1 & $50.0 \%$ & \\
\hline & 4 & 1 & $20.0 \%$ & & & & 4 & 0 & $0.0 \%$ & \\
\hline \multirow[t]{4}{*}{4} & 1 & 0 & $0.0 \%$ & \multirow{4}{*}{$100.0 \%$} & \multirow{4}{*}{-} & 4 & 1 & 0 & - & \multirow{4}{*}{-} \\
\hline & 2 & 0 & $0.0 \%$ & & & & 2 & 0 & - & \\
\hline & 3 & 1 & $50.0 \%$ & & & & 3 & 0 & - & \\
\hline & 4 & 1 & $50.0 \%$ & & & & 4 & 0 & - & \\
\hline
\end{tabular}

Generalising our results, in the case of both-sided single venous system presence, arterial variations were observed in $34.9 \%$ of cases, while in the case of venous system developmental disorders - in $46.8 \%$
(OR: 1.6399, 95\% Cl :1.1444-2.500, $\mathrm{p}=0.007$ ). The above mentioned occurred more often in men, as compared to women (OR: $1.566,95 \% \mathrm{Cl}: 1.0129$ $-2.413, p=0.0436)$. 
Table 5. Arterial-venous coincidence in the vascular bundle of kidney depending on the side of female body $(\mathrm{n}=269)$

\begin{tabular}{|c|c|c|c|c|c|c|c|c|c|c|}
\hline \multicolumn{5}{|c|}{ Right kidney } & \multirow[t]{2}{*}{$\mathbf{P}$} & \multicolumn{5}{|c|}{ Left kidney } \\
\hline $\begin{array}{l}\text { Number } \\
\text { of veins }\end{array}$ & $\begin{array}{l}\text { Number of } \\
\text { arteries }\end{array}$ & $\begin{array}{l}\text { Number of } \\
\text { kidneys }\end{array}$ & $\begin{array}{l}\text { Per } \\
\text { cent }\end{array}$ & $\begin{array}{l}\text { Per cent of super- } \\
\text { numerary arteries }\end{array}$ & & $\begin{array}{l}\text { Number } \\
\text { of veins }\end{array}$ & $\begin{array}{l}\text { Number of } \\
\text { arteries }\end{array}$ & $\begin{array}{c}\text { Number } \\
\text { of kidneys }\end{array}$ & $\begin{array}{l}\text { Per } \\
\text { cent }\end{array}$ & $\begin{array}{l}\text { Per cent of super- } \\
\text { numerary arteries }\end{array}$ \\
\hline \multirow[t]{4}{*}{1} & 1 & 179 & $86.5 \%$ & \multirow{4}{*}{$13.5 \%$} & \multirow{4}{*}{0.297} & 1 & 1 & 214 & $84.3 \%$ & \multirow{4}{*}{$15.7 \%$} \\
\hline & 2 & 26 & $12.6 \%$ & & & & 2 & 39 & $15.4 \%$ & \\
\hline & 3 & 2 & $1.0 \%$ & & & & 3 & 1 & $0.4 \%$ & \\
\hline & 4 & 0 & $0.0 \%$ & & & & 4 & 0 & $0.0 \%$ & \\
\hline \multirow[t]{4}{*}{2} & 1 & 40 & $70.2 \%$ & \multirow{4}{*}{$29.8 \%$} & \multirow{4}{*}{0.45} & 2 & 1 & 9 & $64.3 \%$ & \multirow{4}{*}{$35.7 \%$} \\
\hline & 2 & 14 & $24.6 \%$ & & & & 2 & 4 & $28.6 \%$ & \\
\hline & 3 & 2 & $3.5 \%$ & & & & 3 & 1 & $7.1 \%$ & \\
\hline & 4 & 1 & $1.8 \%$ & & & & 4 & 0 & $0.0 \%$ & \\
\hline \multirow[t]{4}{*}{3} & 1 & 1 & $20.0 \%$ & \multirow{4}{*}{$80.0 \%$} & \multirow{4}{*}{0.333} & 3 & 1 & 1 & $100.0 \%$ & \multirow{4}{*}{$0.0 \%$} \\
\hline & 2 & 2 & $40.0 \%$ & & & & 2 & 0 & $0.0 \%$ & \\
\hline & 3 & 2 & $40.0 \%$ & & & & 3 & 0 & $0.0 \%$ & \\
\hline & 4 & 0 & $0.0 \%$ & & & & 4 & 0 & $0.0 \%$ & \\
\hline \multirow[t]{4}{*}{4} & 1 & 0 & - & \multirow{4}{*}{-} & \multirow{4}{*}{-} & 4 & 1 & 0 & - & \multirow{4}{*}{-} \\
\hline & 2 & 0 & - & & & & 2 & 0 & - & \\
\hline & 3 & 0 & - & & & & 3 & 0 & - & \\
\hline & 4 & 0 & - & & & & 4 & 0 & - & \\
\hline
\end{tabular}

Table 6. Correlation of kidney venous anomalies with other kidney arterial anomalies in 550 cadaver bodies with p-value of chi-square test between men and women

\begin{tabular}{|c|c|c|c|c|c|c|c|c|}
\hline \multirow[t]{3}{*}{ No. } & \multirow{3}{*}{$\begin{array}{l}\text { Type of venous } \\
\text { anomalies }\end{array}$} & \multicolumn{6}{|c|}{ Venous/other kidney arterial anomalies } & \multirow[t]{3}{*}{$\mathbf{P}$} \\
\hline & & \multicolumn{2}{|c|}{ Men } & \multicolumn{2}{|c|}{ Women } & \multicolumn{2}{|c|}{ Total } & \\
\hline & & $\mathbf{N}$ & $\%$ & $\mathbf{N}$ & $\%$ & $\mathbf{N}$ & $\%$ & \\
\hline 1 & & $180 / 72$ & $40.00 \%$ & $184 / 55$ & $29.89 \%$ & $364 / 127$ & $34.89 \%$ & $0.043^{*}$ \\
\hline 2 & & $62 / 38$ & $61.29 \%$ & $50 / 16$ & $32.00 \%$ & $112 / 54$ & $48.21 \%$ & $0.002^{* *}$ \\
\hline 3 & & $7 / 3$ & $42.85 \%$ & $5 / 1$ & $20.00 \%$ & $12 / 4$ & $33.33 \%$ & 0.408 \\
\hline 4 & & $6 / 6$ & $100.00 \%$ & $6 / 4$ & $66.66 \%$ & $12 / 10$ & $83.33 \%$ & 0.121 \\
\hline 5 & & $13 / 4$ & $30.76 \%$ & $10 / 1$ & $23.50 \%$ & $23 / 5$ & $21.73 \%$ & 0.699 \\
\hline 6 & & $2 / 1$ & $50.00 \%$ & $4 / 2$ & $50.00 \%$ & $6 / 3$ & $50.00 \%$ & 1.000 \\
\hline 7 & & $11 / 7$ & $63.63 \%$ & $10 / 4$ & $40.00 \%$ & $21 / 11$ & $52.38 \%$ & 0.279 \\
\hline Total & & 281/131 & $46.61 \%$ & $269 / 83$ & $30.85 \%$ & $550 / 214$ & $38.90 \%$ & $0.0002^{* * *}$ \\
\hline
\end{tabular}

${ }^{*} \mathrm{p}<0.05,{ }^{* *} \mathrm{p}<0.01,{ }^{* * *} \mathrm{p}<0.001$

Considering the clinical aspect, we presented the percentage of additional renal artery topographic variations, in relation to the veins. Considering male patients, $4.3 \%$ of right-sided additional arteries presented with a precaval course, while in female patients - 3\% (Fig. 1). Apart from the above-mentioned, in $3.2 \%$ of male, and in $0.7 \%$ of female, the right additional artery wrapped around the renal vein. 
On the left side, the above-mentioned phenomenon was observed in $2.13 \%$ of male and $0.36 \%$ of female (Fig. 2).

\section{DISCUSSION}

Our investigations showed significant coexistence of venous and arterial developmental anomalies, considering the renal vascular bundle. Based on the performed angiographies, Baptista-Silva et al. [3] observed more than one renal artery, being convinced of finding two or more additional renal veins. The existence of such anatomical variants should be taken under consideration, in the prevention of bleeding during retroperitoneal space and abdominal aortic surgery $[2,3]$. The mentioned anomalies result from the complicated development of the vasculorenal system, which was thoroughly described in our previous studies [27, 28]. Generally speaking, an embryo $14-16 \mathrm{~mm}$ in length (6-8 weeks of development), is subjected to mesonephros ascend from the pelvis to the lumbar area with simultaneous atrophy of lower arteries and the development of novel abdominal aortic vessels $[21,29]$. At the same time, the venous system develops from three successive and degenerative, cardinal veins. One may observe many transverse and anterodorsal connections between them. Thus, the aorta and renal artery branches are connected in the network of numerous venous vessels, and blood initially flowing to the heart symmetrically, is shifted to the right side. At the same time, the inferior caval vein develops from four separate fragments. These complicated processes favour the development of the mentioned anomalies. We do not know the final cause of their development. In our research, considering a normal venous structure (both-sided, single vein), arterial variants were observed in $34.9 \%$, while in the case of developmental disorders - in $46.8 \%$. Pick and Anson [21] showed the existence of a single artery and vein on both sides in only $38.5 \%$.

For transplantation purposes, cases with one renal artery are desired [6]. However, due to the increased demand for transplantation material and ageing population, no material is discarded. Thus, knowledge of the described anomalies, as well as introduction of different surgical techniques seems especially important [7]. Transplantations with the presence of the abovementioned anomalies are safe, if performed by an experienced team. Fast diagnosis and proper treatment protect both the transplanted organ and the patient. However, vascular complications are observed in $2.55 \%$ to $13.5 \%[1,2,4,8,25]$. Amongst them, the most important include rupture of arterial anastomoses, which might lead to transplant rejection, and even lower leg loss [18]. Bleeding was observed in $2.8 \%$ and stenotic vascular complications in $0.9 \%$ [19], $1.5 \%$ [5], and $3.17 \%$, [6], respectively. Vascular complications occurred significantly more often in the case of a transplant with many vessels, as compared to a single renal artery transplant. The above-mentioned was associated with prolonged surgery and transplant ischaemia $[14,15,19$, $24,25]$, which had, however, no negative influence on its future functioning. The described complications were reduced with the development of operative techniques and acquired surgical knowledge of the operating team $[4,9,18]$.

The mentioned problems concerning arterial complications may also apply to venous damage complications. Variants in their structure were observed in $33.8 \%$, mainly on the right side (20.4\%) [28]. Pick and Anson [21] noted such complications in $27.8 \%$ of cases. Bleeding was observed in $25.4 \%$, and venous anastomoses stenosis in $8.2 \%$ [19]. Veins do not pulsate, are subject to rupture, and are difficult to distinguish from adhesions [21].

Considering patients operated for abdominal aortic aneurysms, knowledge of venous anomalies, especially on the left side, seems very important. The above-mentioned veins are often hidden in the adhesions, and overlooked [2, 26]. Understanding the possible existence of particular venous anomalies, and especially precise computed tomography image analysis before surgery, as well as effective surgical technique are conditions, which minimalise the occurrence of these complications [13].

The retroaortic course of the left renal vein was observed in only $1.4 \%$ of cases [3]. Considering our material, these figures amounted to $12.4 \%$. The compression of the vein by the aorta led to the clinical diagnosis of haematuria in a 13-year-old boy [10].

Considering the presented material, $4.3 \%$ male and $3 \%$ female cases showed a precaval course of right-sided additional renal arteries. These cases do not exclude kidney transplantation [22].

Compression of renal veins by surrounding additional renal arteries was observed in $3.2 \%$ of male and $0.74 \%$ female cases, on the right side. On the other hand, $2.13 \%$ of male and $0.36 \%$ of female cases on the left side. Nathan came to similar conclusions, considering a study material of 200 analysed corpses; but he observed $6 \%$ of such cases on the left side, 
and only $1 \%$ on the right one [17]. It is generally accepted that increased kidney venous system pressure might lead to orthostatic proteinuria. In search of the cause of proteinuria one should not forget about the mentioned possibility.

\section{CONCLUSIONS}

The coexistence of renal, venous and arterial, developmental anomalies in the vascular bundle is significantly correlated. It occurs especially often in men; therefore, the female kidney is preferred for transplantation.

\section{REFERENCES}

1. Aktas S, Boyvat F, Sevmis $S$, et al. Analysis of vascular complications after renal transplantation. Transplant Proc. 2011; 43(2): 557-561, doi: 10.1016/j.transproceed.2011.01.007, indexed in Pubmed: 21440760.

2. Aljabri B, MacDonald PS, Satin R, et al. Incidence of major venous and renal anomalies relevant to aortoiliac surgery as demonstrated by computed tomography. Ann Vasc Surg. 2001; 15(6): 615-618, doi: 10.1007/s10016-001-0095-7, indexed in Pubmed: 11769141.

3. Baptista-Silva J, Veríssimo M, Castro M, et al. Anatomical study of the renal veins observed during 342 livingdonor nephrectomies. Sao Paulo Med J. 1997; 115(3): 1456-1459, doi: 10.1590/s1516-31801997000300011.

4. Bessede T, Droupy S, Hammoudi Y, et al. Surgical prevention and management of vascular complications of kidney transplantation. Transpl Int. 2012; 25(9): 994-1001, doi: 10.1111/j.14322277.2012.01533.x, indexed in Pubmed: 22816523.

5. Bude RO, Forauer AR, Caoili EM, et al. Is it necessary to study accessory arteries when screening the renal arteries for renovascular hypertension? Radiology. 2003; 226(2): 411-416, doi: 10.1148/radiol.2263011576, indexed in Pubmed: 12563134.

6. Carter JT, Freise CE, McTaggart RA, et al. Laparoscopic procurement of kidneys with multiple renal arteries is associated with increased ureteral complications in the recipient. Am J Transplant. 2005; 5(6): 1312-1318, doi: 10.1111/j.16006143.2005.00859.x, indexed in Pubmed: 15888035.

7. De Rosa P, Santangelo M, Scala A, et al. Difficult vascular conditions in kidney transplantation. Transplant Proc. 2006; 38(4): 1040-1043, doi: 10.1016/j.transproceed.2006.03.073.

8. Eufrásio $P$, Parada $B$, Moreira $P$, et al. Surgical complications in 2000 renal transplants. Transplant Proc. 2011; 43(1): 142-144, doi: 10.1016/j.transproceed.2010.12.009.

9. Gentil Govantes MA, Rodriguez-Benot A, Sola E, et al. Trends in kidney transplantation outcome: the Andalusian Kidney Transplant Registry, 1984-2007. Transplant Proc. 2009; 41(5): 1583-1585, doi: 10.1016/j.transproceed.2009.01.094, indexed in Pubmed: 19545684.

10. Gibo M, Onitsuka H. Retroaortic left renal vein with renal vein hypertension causing hematuria. Clin Imaging. 1998; 22(6): 422-424, indexed in Pubmed: 9876912.

11. Gupta A, Gupta R, Singal R. Congenital variations of renal veins: embryological background and clinical implications. J Clin Diagn Res. 2011; 5(Suppl 1): 1140.

12. Hennayake $S$. Prone retroperitoneoscopy in treating complex renal vascular malformations. J Pediatr Urol. 2010; 6(2): 192-197, doi: 10.1016/j.jpurol.2009.06.014, indexed in Pubmed: 19664958.

13. Karkos CD, Bruce IA, Thomson GJ, et al. Retroaortic left renal vein and its implications in abdominal aortic surgery. Ann Vasc Surg. 2001; 15(6): 703-708, doi: 10.1007/s10016001-0022-y, indexed in Pubmed: 11769156.
14. Keller JE, Dolce CJ, Griffin D, et al. Maximizing the donor pool: use of right kidneys and kidneys with multiple arteries for live donor transplantation. Surg Endosc. 2009; 23(10): 2327-2331, doi: 10.1007/s00464-009-0330-9, indexed in Pubmed: 19263162.

15. Lim YMJ, Han X, Raman L, et al. Outcome of living donor transplant kidneys with multiple arteries. Transplant Proc. 2016; 48(3): 848-851, doi: 10.1016/j.transproceed.2015.12.104, indexed in Pubmed: 27234750.

16. Madhyastha $S$, Suresh R, Rao R. Multiple variations of renal vessels and ureter. Indian J Urol. 2001; 17: 164.

17. Nathan H. Observations on aberrant renal arteries curving around and compressing the renal vein; possible relationship to orthostatic proteinuria and to orthostatic hypertension. Circulation. 1958; 18(6): 1131-1134, indexed in Pubmed: 13608842.

18. Orlic P, Vukas D, Drescik I, et al. Vascular complications after 725 kidney transplantations during 3 decades. Transplantation Proceedings. 2003; 35(4): 1381-1384, doi: 10.1016/s0041-1345(03)00506-2.

19. Osman Y, Shokeir A, Ali-el-Dein B, et al. Vascular complications after live donor renal transplantation: study of risk factors and effects on graft and patient survival. J Urol. 2003; 169(3): 859-862, doi: 10.1097/01. ju.0000050225.74647.5a, indexed in Pubmed: 12576799.

20. Paragi PR, Klaassen Z, Fletcher HS, et al. Vascular constraints in laparoscopic renal allograft: comparative analysis of multiple and single renal arteries in 976 laparoscopic donor nephrectomies. World J Surg. 2011; 35(9): 2159-2166, doi: 10.1007/s00268-011-1168-6, indexed in Pubmed: 21713578.

21. Pick J, Anson B. The renal vascular pedicle: an anatomical study of 430 body-halves. J Urol. 1940; 44(4): 411-434, doi: 10.1016/s0022-5347(17)71289-x.

22. Radolinski B, Diner EK, Ghasemian SR. Precaval right renal artery during laparoscopic donor nephrectomy. Transplantation. 2006; 82(11): 1554-1555, doi: 10.1097/01. tp.0000243738.44921.e2, indexed in Pubmed: 17164737.

23. Reis RH, Esenther G. Variations in the pattern of renal vessels and their relation to the type of posterior vena cava in man. Am J Anat. 1959; 104: 295-318, doi: 10.1002/ aja.1001040206, indexed in Pubmed: 14437208.

24. Saidi R, Kawai T, Kennealey P, et al. Living donor kidney transplantation with multiple arteries: recent increase in modern era of laparoscopic donor nephrectomy. Arch Surg. 2009; 144(5): 472-475, doi: 10.1001/archsurg.2009.49, indexed in Pubmed: 19451491.

25. Salehipour M, Salahi $H$, Jalaeian $H$, et al. Vascular complications following 1500 consecutive living and cadaveric donor renal transplantations: a single center study. Saudi J Kidney Dis Transpl. 2009; 20(4): 570-572, indexed in Pubmed: 19587495.

26. Shindo S, Kubota K, Kojima A, et al. Anomalies of inferior vena cava and left renal vein: risks in aortic surgery. Ann Vasc Surg. 2000; 14(4): 393-396, indexed in Pubmed: 10943793.

27. Sośnik H, Sośnik K. Investigations on renal vascularisation pathology in the Polish population. 1. Incidence of multiple kidney arteries. Folia Morphol. 2017; 76(2): 226-231, doi: 10.5603/FM.a2016.0073, indexed in Pubmed: 28026854

28. Sośnik H, Sośnik K. Renal vascularization anomalies in the Polish population. Pol Przegl Chir. 2017; 89(6): 26-30, doi: 10.5604/01.3001.0010.6760, indexed in Pubmed: 29335391.

29. Watson CJE, Harper SJF. Anatomical variation and its management in transplantation. Am J Transplant. 2015; 15(6): 1459-1471, doi: 10.1111/ajt.13310, indexed in Pubmed: 25981150.

30. Yahiro J, Miyoshi S. Double left renal veins and multiple right renal veins found in Japanese adults. Okajimas Folia Anat Jpn. 1993; 70(5): 237-245, indexed in Pubmed: 8202308. 